Tetrahedron Letters

journal homepage: www.elsevier.com

\title{
Isomer-sensitive deboronation in reductive aminations of aryl boronic acids
}

\author{
Brad H. Jones ${ }^{\mathrm{a}, *}$, David R. Wheeler ${ }^{\mathrm{b}}$, Jill S. Wheeler ${ }^{\mathrm{c}}$, Lance L. Miller ${ }^{\mathrm{d}}$, Todd M. Alam ${ }^{\mathrm{a}}$, and Erik D. \\ Spoerke ${ }^{\mathrm{c}}$
}

${ }^{a}$ Organic Materials Science, Sandia National Laboratories, Albuquerque, NM 87185 USA

${ }^{b}$ Special Technologies, Sandia National Laboratories, Albuquerque, NM 87185, USA

${ }^{c}$ Electronic, Optical, and Nano Materials, Sandia National Laboratories, Albuquerque, NM 87185, USA

${ }^{d}$ Materials Reliability, Sandia National Laboratories, Albuquerque, NM 87185, USA

\section{ARTICLE INFO}

Article history:

Received

Received in revised form

Accepted

Available online

\section{Keywords:}

Boronic acid

Reductive amination

Peptide modification

Deboronation

Formylphenylboronic acid

\section{ABSTRACT}

Deboronation is observed during the reductive amination of formylphenylboronic acid (FPBA) to the amine termini and side chains of peptides. This deboronation is sensitive to the isomerism of the boronic acid (BA), with ortho-FPBA yielding complete deboronation in the preparation of an $\mathrm{N}$-terminally-modified dipeptide. The observed behavior is also clearly mediated by the chemical identity of the amine substrate. These results reveal a previously undocumented subtlety of BA functionalization and highlight the importance of thorough spectroscopic characterization in the preparation of peptide and small molecule BAs.

(C) 2015 Elsevier Ltd. All rights reserved.
Boronic acids (BAs) are useful functionalities for programmable stimuli-responsive chemistry, due to their Lewis acid character with $\mathrm{pK}_{\mathrm{a}}$ values tunable across physiological $\mathrm{pH}$ and their reversible binding to saccharides, catechols, and other compounds bearing 1,2-diol moieties. ${ }^{1}$ In addition, BAs have emerged as valuable reagents and intermediates in important synthetic pathways, such as Suzuki cross-coupling reactions, ${ }^{1}$ and as selective enzyme inhibitors, exemplified by the commercial success of the anti-cancer drug Bortezomib. ${ }^{2}$ Over the last decade, researchers have studied a variety of BA-modified peptides, focusing on the inhibitory properties of the BA or the use of the BA as a functional element in peptide self-assembly. ${ }^{3}$ For example, our group has recently reported the reversible selfassembly behavior of a BA dipeptide, controllable by $\mathrm{pH}$, ionic strength, and the addition of polyols. ${ }^{3 \mathrm{~s}}$

BAs are frequently attached to peptides, and more generally a variety of small molecules, via conventional acid-amine coupling chemistry or reductive aminations. More specifically, formylphenylboronic acid (FPBA) has been used in solid phase peptide synthesis to graft the phenylboronic acid functionality through lysine side chains of the peptide via reductive amination. ${ }^{3 \mathrm{~g}, 3 \mathrm{k}, 4}$ In addition, a variety of small molecule BAs have been derived from reductive aminations involving FPBA. ${ }^{5}$ Although several pathways are known by which deboronation of BA compounds can occur, most notably by strong oxidants such as peroxides, ${ }^{1}$ deboronation has not been reported in reductive aminations. However, some groups have noted instability of
ortho-FPBAs to the borohydride reducing agents typical of such aminations, resulting in the formation of benzoxaborole species. $^{5 \mathrm{j}, 51,5 \mathrm{~m}, 50,6}$

Based on the past literature, then, we were surprised to discover that reductive amination of ortho-FPBA to the $N$ terminus of a simple dipeptide resulted in a product (2) completely devoid of boron. Briefly, the dipeptide of phenylalanine (Phe-Phe), resin-bound at its $C$-terminus and bearing a deprotected $N$-terminus was shaken with an excess of ortho-FPBA and sodium cyanoborohydride, $\mathrm{NaCNBH}_{3}$, predissolved in dimethylformamide (DMF). Additional synthetic details are provided in the Supplementary Information. Extensive deboronation was also similarly observed in the reductive amination of ortho-FPBA to the lysine side chain of a linear nonapeptide (3, Figures S1-S3). In contrast, the reductive amination of para-FPBA to the same dipeptide gives a product (1) that is more consistent with the expected outcome of amination, i.e., there was little apparent deboronation.

Figure 1 shows the result of electrospray ionization-mass spectrometry (ESI-MS) performed on the $N$-terminally modified peptides obtained using the para and ortho isomers of FPBA. The spectrum for the para product 1 (Figure 1a) shows the expected $[\mathrm{M}-\mathrm{H}]^{-}$ion indicating the successful attachment of FPBA, as well as a small signature of the unmodified dipeptide, $[\mathrm{M}-\mathrm{H}-\mathrm{FPBA}]^{-}$. Furthermore, the $[\mathrm{M}-\mathrm{H}]^{-}$ion exhibits isotopic splitting characteristic of boron; namely, the principal peak is preceded by a peak less one $\mathrm{Da}$, reflecting the natural occurrence 
of ${ }^{10} \mathrm{~B}$. The spectrum for the ortho product 2 (Figure $1 \mathrm{~b}$ ) instead shows a product that is $18 \mathrm{Da}$ less than the expected $[\mathrm{M}-\mathrm{H}]^{-}$ion. Indeed, this product no longer exhibits the isotopic splitting characteristic of boron, suggesting the elimination of $\mathrm{B}(\mathrm{OH})$ from the product. ${ }^{1} \mathrm{H},{ }^{11} \mathrm{~B}$, and ${ }^{13} \mathrm{C}$ nuclear magnetic resonance (NMR) spectroscopy (Figures S4, S5, and S7) confirms these ESI-MS results. Specifically, the para product shows a single ${ }^{11} \mathrm{~B}$ resonance with a chemical shift consistent with typical BAs, whereas the ortho product shows no ${ }^{11} \mathrm{~B}$ signal whatsoever. In addition, the ortho product exhibits a distinct ${ }^{13} \mathrm{C}$ resonance at $156 \mathrm{ppm}$ that is not found in the para product, consistent with an aromatic carbon adjacent to a hydroxyl substituent. ${ }^{7}$ On the basis of these results, we postulate the reactions drawn in Scheme 1.
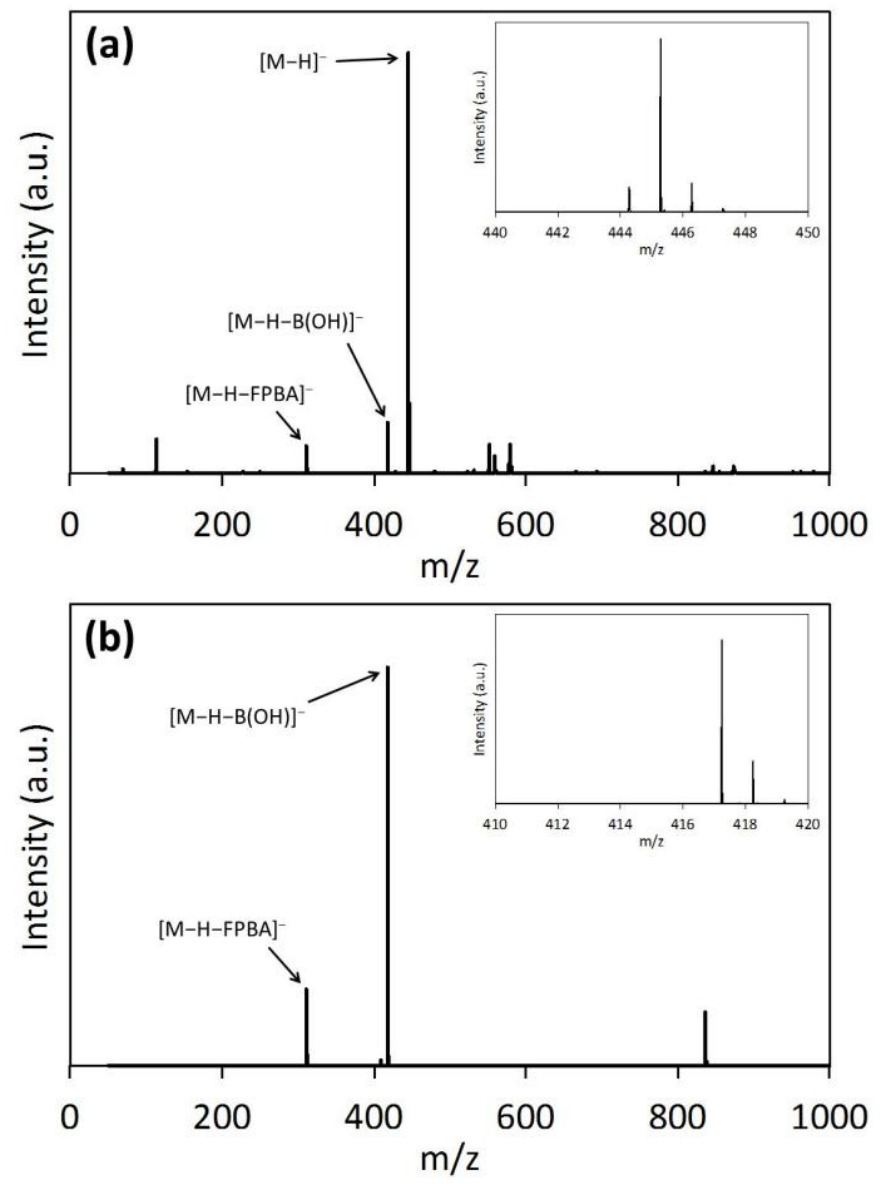

Figure 1. Negative mode ESI-MS of Phe-Phe $N$-terminally modified by reductive amination of (a) para-FPBA and (b) ortho-FPBA. M indicates $446.2 \mathrm{Da}$, the mass of the desired, BAmodified dipeptide. The insets show the isotopic splitting of the highest intensity peak in each spectrum.

We subsequently found that FPBA further exhibits an isomersensitive stability of the aldehyde functionality when exposed to the reducing agent $\mathrm{NaCNBH}_{3}$. When para-FPBA is exposed to $\mathrm{NaCNBH}_{3}$ in $\mathrm{d}_{7}$-DMF, ${ }^{1} \mathrm{H}$ NMR spectroscopy shows no apparent change in the identity of the FPBA (Figure 2a). In contrast, when ortho-FPBA is exposed to $\mathrm{NaCNBH}_{3}$, the aldehyde functionality is clearly lost, with the appearance of a new proton signal well upfield of the original aldehyde proton (Figure $2 b$ ). In addition, the corresponding ${ }^{11} \mathrm{~B}$ NMR spectra clearly show that the BA functionality is unstable only in the case of the ortho isomer (Figure S9). These data collectively suggest the reduction of ortho-FPBA to the corresponding benzoxaborole 4 by $\mathrm{NaCNBH}_{3}$, in agreement with previously reported data. ${ }^{5 \mathrm{j}, 51,5 \mathrm{~m}, 5 \mathrm{o}, 6}$ Indeed, the NMR spectra of a commercially available sample of the hemiester of 2-(hydroxymethyl)phenylboronic acid (Figure
S10) were consistent with the NMR spectra of the reduced orthoFPBA. Similar results were obtained when $\mathrm{CD}_{3} \mathrm{OD}$ was used as the solvent (Figure S11 and Figure S12), although reduction of para-FPBA was also evident over longer time scales (Figure $\mathrm{S} 13)$.Scheme 1. Isomer-sensitive deboronation in $\mathrm{N}$-terminal modification of Phe-Phe by reductive amination of FPBA.
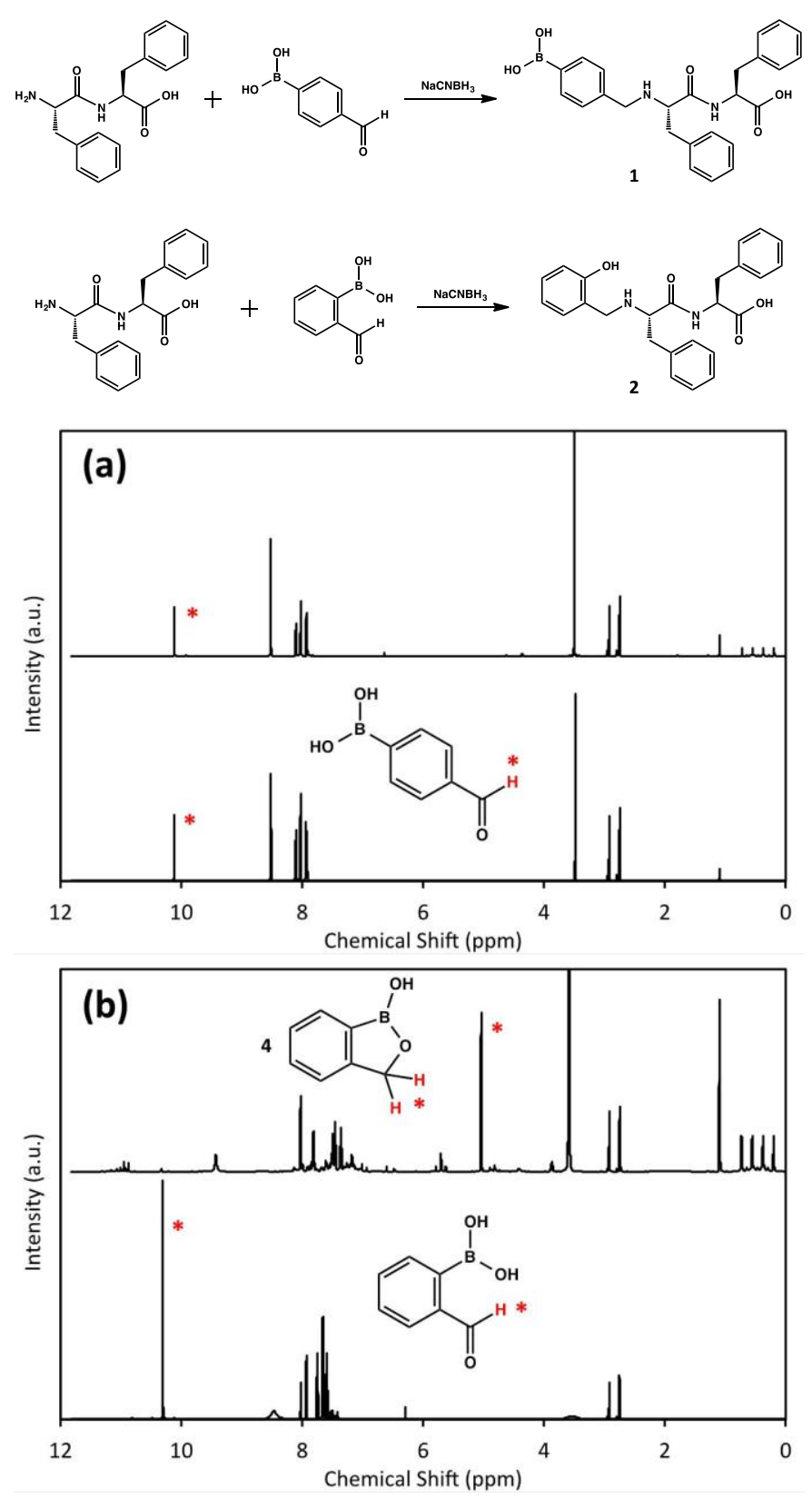

Figure 2. ${ }^{1} \mathrm{H}$ NMR spectra showing isomer-dependent sensitivity of (a) para-FPBA and (b) ortho-FPBA to reducing agent $\mathrm{NaCNBH}_{3}$. In both panels, the bottom spectrum shows the neat FPBA in $\mathrm{d}_{7}-\mathrm{DMF}$, while the top spectrum shows the FPBA in $\mathrm{d}_{7^{-}}$ DMF after addition of $\mathrm{NaCNBH}_{3}$. The proton signals indicating the stability of para-FPBA to $\mathrm{NaCNBH}_{3}$ and the reduction of ortho-FPBA by $\mathrm{NaCNBH}_{3}$ to the corresponding benzoxaborole 4 are denoted by the red asterisks.

These data led us to consider the possibility that isomerdependent deboronation was associated in some manner with the instability of ortho-FPBA to reducing agents. Therefore, we repeated the reductive amination as a two-step process, first reacting the $N$-terminus of the peptide with ortho-FPBA to give the usual imine species, and then reducing the imine via $\mathrm{NaCNBH}_{3}$. However, in this case, the identical deboronated 
product 2 was obtained (Figure S14). Thus, both the reduction of ortho-FPBA to the benzoxaborole followed by exposure to an amine, and the formation of an imine between ortho-FPBA and an amine followed by exposure to $\mathrm{NaCNBH}_{3}$, leads to installation of the phenyl ring as a deboronated substituent (Scheme 2).

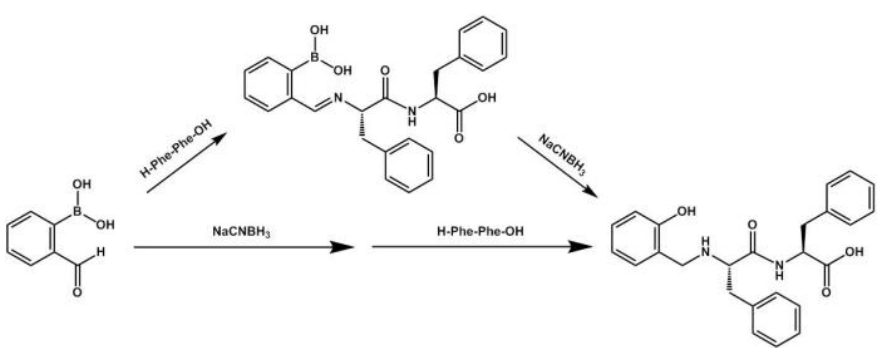

Scheme 2. A deboronated product is observed independent of the order of amination and reduction.

To provide further insight into the origin of deboronation in these reactions, as well as to explore its generality, we conducted NMR experiments tracking a solution-based reductive amination of FPBA to different primary amines. Figure 3 shows the result of ${ }^{1} \mathrm{H}$ and ${ }^{11} \mathrm{~B}$ NMR spectroscopy performed on a mixture of ortho-FPBA and $\mathrm{H}$-Phe-Phe- $\mathrm{NH}_{2}$ in $\mathrm{d}_{7}-\mathrm{DMF}$, to which $\mathrm{NaCNBH}_{3}$ is subsequently added (3:3:1 [FPBA]:[NaCNBH 3$]:[\mathrm{H}-$ Phe-Phe- $\left.\mathrm{NH}_{2}\right]$ ). H-Phe-Phe- $\mathrm{NH}_{2}$ was used in this experiment instead of $\mathrm{H}-\mathrm{Phe}-\mathrm{Phe}-\mathrm{OH}$ (Scheme 2) because of the poor solubility of the latter in DMF and $\mathrm{MeOH}$. As expected, the ${ }^{1} \mathrm{H}$ spectrum in Figure 3a indicates attachment of a substituent to the $\mathrm{N}$-terminus of the peptide, along with the reduction of excess ortho-FPBA to benzoxaborole. In addition, a prominent resonance is found at $6.8 \mathrm{ppm}$, this resonance being absent in the spectra of the benzoxaborole (Figure $2 \mathrm{~b}$ and Figure S10), H-PhePhe- $\mathrm{NH}_{2}$ (Figure S15), and a mixture of ortho-FPBA and H-PhePhe- $\mathrm{NH}_{2}$ (Figure S17). In oxidative deboronation reactions, a distinct upfield shift of aromatic resonances has been previously shown to accompany the conversion of phenylboronic acids to phenols. ${ }^{8}$ The ${ }^{11} \mathrm{~B}$ spectrum in Figure $3 \mathrm{~b}$, as expected, indicates reduction of excess ortho-FPBA to the benzoxaborole. However, there is also a distinct resonance at $20 \mathrm{ppm}$, consistent with the formation of boric acid as the byproduct of deboronation (see Figure S18 for the NMR spectra of neat boric acid).

Interestingly, none of the aforementioned features are observed in the corresponding NMR spectra when a simple aliphatic amine is substituted for the dipeptide in these reductive aminations. Instead, both the ${ }^{1} \mathrm{H}$ and ${ }^{11} \mathrm{~B}$ spectra (Figure S19) suggest successful installation of the phenylboronic acid with no conspicuous loss of the boronic acid functionality, i.e., liberation of boric acid. This observation is consistent with the relatively widespread and apparently successful use of ortho-FPBA in reductive aminations for the preparation of aminomethylphenylboronic acids. ${ }^{3 \mathrm{~g}, 3 \mathrm{k}, 4-5,9}$

Based on this collective information, it is therefore apparent that the deboronation phenomenon observed is influenced by not only the isomerism of the boronic acid, but also the chemical identity of the amine substrate. Related phenomena have been reported recently for several chemical reactions involving boronic acids. ${ }^{8,10}$ For example, Fu, et al., reported that secondary amines catalyze air oxidation of aryl boronic acids and boronate esters to the corresponding phenols, while primary and tertiary amines do not, due to the relative basicity of amines: $2^{\circ}>1^{\circ}>$ $3^{\circ}{ }^{8 \mathrm{~b}}$ Their work could implicate the secondary amine resulting from imine reduction as having a critical role in deboronation; however, ortho-substituted products, unlike para-substituted ones, can form a B-N dative bond accompanied by decreased basicity of the amine, ${ }^{5 a}$ which is contrary to the poorer stability of the ortho-substituted product we have observed. Other work has shown oxidation of aryl boronic acids to be dramatically accelerated by the presence of electron-withdrawing substituents on the phenyl ring, yet the aminomethyl substituents at present are electron-donating in character. ${ }^{10 \mathrm{~b}}$ Thus, the mechanism of deboronation at present is decidedly more subtle. Cammidge and coworkers, ${ }^{8 \mathrm{a}}$ and Zhu and coworkers, ${ }^{10 \mathrm{a}}$ have found that catalytic amounts of certain quinones and $N$-oxides, respectively, can effect deboronation of various aryl boronic acids. We suspect a similar process is occurring here, wherein the peptide catalyzes deboronation to which the ortho-substituted boronic acid is particularly susceptible.
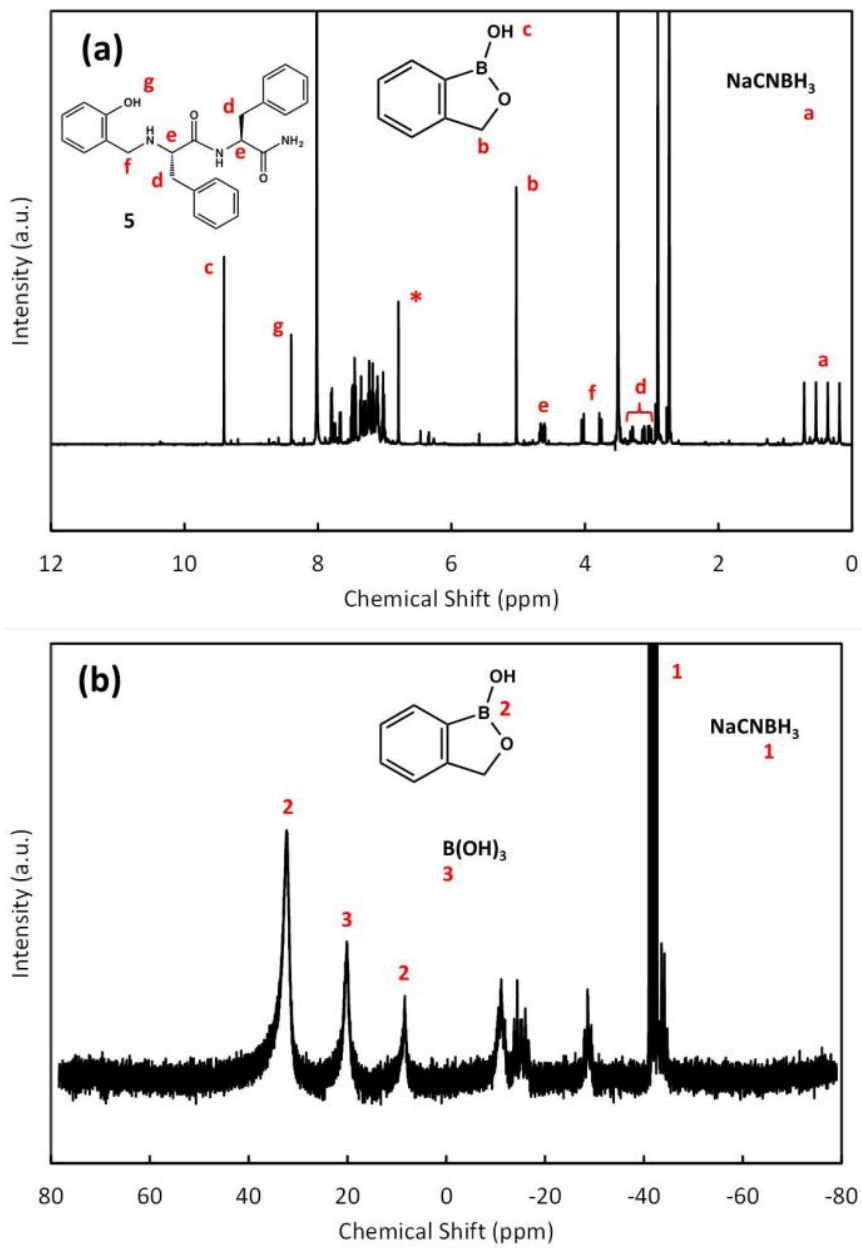

Figure 3. (a) ${ }^{1} \mathrm{H}$ and (b) ${ }^{11} \mathrm{~B}$ NMR spectra of reductive amination of ortho-FPBA to H-Phe-Phe- $\mathrm{NH}_{2}$ with $\mathrm{NaCNBH}_{3}$ as reducing agent. The solvent is $\mathrm{d}_{7}$-DMF. Deboronation is suggested by the appearance of a new aromatic resonance in the ${ }^{1} \mathrm{H}$ spectrum, marked by the red asterisk, as well as the appearance of a new resonance in the ${ }^{11} \mathrm{~B}$ spectrum corresponding to liberation of boric acid.

Although additional work is required to elucidate further the mechanism and details of deboronation that we have observed, we feel the present results serve as an important cautionary account, particularly in light of increasing interest in peptide and small molecule BAs. ESI-MS is regularly used to confirm the outcome of solid phase peptide synthesis, and deboronation has been reported as an artifact of in-source fragmentation of aryl BAs. ${ }^{11}$ However, our combined MS and NMR characterizations have clearly shown that extensive deboronation can occur during 
the reductive amination of ortho-FPBA to peptide substrates. Therefore, the signatures of deboronation in MS must be given careful consideration when determining the outcome of peptide BA syntheses. If isomerism of the boronic acid is irrelevant, the improved stability of para-FPBA to $\mathrm{NaCNBH}_{3}$ appears to advocate its use in reductive amination schemes. Alternatively, we recommend the use of carboxyphenylboronic acids, which can be used to install BAs onto peptides via standard acid-amine coupling chemistry (exemplified by compound 6, Figures S20S22) with no apparent deboronation.

\section{Acknowledgments}

We gratefully acknowledge James Hochrein for use of MS equipment and Alina Martinez for performing HPLC. This research was supported by the US Department of Energy, Office of Basic Energy Sciences, Division of Materials Science and Engineering, Project KC0203010. Sandia National Laboratories is a multi-program laboratory operated by Sandia Corporation, a wholly owned subsidiary of Lockheed Martin Corporation, for the US Department of Energy's National Nuclear Security Administration under contract DE-AC04-94AL85000.

\section{References}

1. Hall, D. G. In Boronic Acids: Preparation and Applications in Organic Synthesis and Medicine; Hall, D. G., Ed.; Wiley-VCH: Weinheim, Germany, 2005; pp 1-100.

2. Fu, H.; Fang, H.; Sun, J.; Wang, H.; Liu, A.; Sun, J.; Wu, Z. Curr. Med. Chem. 2014, 21, 3271-3280.

3. (a) Kettner, C.; Mersinger, L.; Knabb, R. J. Biol. Chem. 1990, 265, 18289-18297; (b) Elgendy, S.; Deadman, J.; Patel, G.; Green, D.; Chino, N.; Goodwin, C. A.; Scully, M. F.; Kakkar, V. V.; Claeson, G. Tetrahedron Lett. 1992, 33, 4209-4212; (c) Kimura, T.; Takeuchi, M.; Nagasaki, T.; Shinkai, S. Tetrahedron Lett. 1995, 36, 559-562; (d) McCormack, T.; Baumeister, W.; Grenier, L.; Moomaw, C.; Plamondon, L.; Pramanik, B.; Slaughter, C.; Soucy, F.; Stein, R.; Zühl, F.; Dick, L. J. Biol. Chem. 1997, 272, 2610326109; (e) Kobayashi, H.; Koumoto, K.; Hwa Jung, J.; Shinkai, S. J. Chem. Soc. Perk. T. 2 2002, 1930-1936; (f) Duggan, P. J.; Offermann, D. A. Aust. J. Chem. 2007, 60, 829-834; (g) Edwards, N. Y.; Sager, T. W.; McDevitt, J. T.; Anslyn, E. V. J. Am. Chem. Soc. 2007, 129, 13575-13583; (h) LeBeau, A. M.; Singh, P.; Isaacs, J. T.; Denmeade, S. R. Chem. Biol. 2008, 15, 665-674; (i) Chen, C. S.; Ji, T. J.; Xu, X. D.; Zhang, X. Z.; Zhuo, R. X. Macromol. Rapid Commun. 2010, 31, 1903-1908; (j) Knott, K.; Fishovitz, J.; Thorpe, S. B.; Lee, I.; Santos, W. L. Org. Biomol. Chem. 2010, 8, 3451-3456; (k) Bicker, K. L.; Sun, J.; Lavigne, J. J.; Thompson, P. R. ACS Comb. Sci. 2011, 13, 232-243; (1) Ikeda, M.; Tanida, T.; Yoshii, T.; Hamachi, I. Adv. Mater. 2011, 23, 2819-2822; (m) Xu, X. D.; Chu, Y. F.; Chen, C. S.; Chen, J. X.; Cheng, S. X.; Zhang, X. Z.; Zhuo, R. X. Small 2011, 7, 2201-2209; (n) Chen, C. S.; Xu, X. D.; Wang, Y.; Yang, J.; Jia, H. Z.; Cheng, H.; Chu, C. C.; Zhuo, R. X.; Zhang, X. Z. Small 2013, 9, 920-926; (o) Melicher, M. S.; Chu, J.; Walker, A. S.; Miller, S. J.; Baxter, R. H. G.; Schepartz, A. Org. Lett. 2013, 15, 5048-5051; (p) Ren, J.; Zhang, Y.; Zhang, J.; Gao, H.; Liu, G.; Ma, R.; An, Y.; Kong, D.; Shi, L. Biomacromolecules 2013, 14, 34343443; (q) Ikeda, M.; Tanida, T.; Yoshii, T.; Kurotani, K.; Onogi, S.;
Urayama, K.; Hamachi, I. Nat. Chem. 2014, 6, 511-518; (r) Neupane, L. N.; Han, S. Y.; Lee, K. H. Chem. Commun. 2014, 50, 5854-5857; (s) Jones, B. H.; Martinez, A. M.; Wheeler, J. S.; McKenzie, B. B.; Miller, L. L.; Wheeler, D. R.; Spoerke, E. D. Chem. Commun. 2015, DOI: $10.1039 / \mathrm{C} 5 \mathrm{CC} 05207 \mathrm{~F}$.

4. Heinrichs, G.; Schellenträger, M.; Kubik, S. Eur. J. Org. Chem. 2006, 2006, 4177-4186.

5. (a) Wiskur, S. L.; Lavigne, J. J.; Ait-Haddou, H.; Lynch, V.; Chiu, Y. H.; Canary, J. W.; Anslyn, E. V. Org. Lett. 2001, 3, 1311-1314; (b) Gray, C. W.; Houston, T. A. J. Org. Chem. 2002, 67, 5426-5428; (c) Johnson, L. L.; Houston, T. A. Tetrahedron Lett. 2002, 43, 89058908; (d) Asano, T.; Nakamura, H.; Uehara, Y.; Yamamoto, Y. ChemBioChem 2004, 5, 483-490; (e) Bosch, L. I.; Fyles, T. M.; James, T. D. Tetrahedron 2004, 60, 11175-11190; (f) Luvino, D.; Smietana, M.; Vasseur, J.-J. Tetrahedron Lett. 2006, 47, 9253-9256; (g) Tan, W.; Zhang, D.; Zhu, D. Bioorg. Med. Chem. Lett. 2007, 17, 2629-2633; (h) Adamczyk-Woźniak, A.; Brzózka, Z.; Cyrański, M. K.; Filipowicz-Szymańska, A.; Klimentowska, P.; Żubrowska, A.; Żukowski, K.; Sporzyński, A. Appl. Organomet. Chem. 2008, 22, 427-432; (i) Adamczyk-Woźniak, A.; Cyrański, M. K.; Żubrowska, A.; Sporzyński, A. J. Organomet. Chem. 2009, 694, 3533-3541; (j) Adamczyk-Woźniak, A.; Cyrański, M. K.; Jakubczyk, M.; Klimentowska, P.; Koll, A.; Kołodziejczak, J.; Pojmaj, G.; Żubrowska, A.; Żukowska, G. Z.; Sporzyński, A. J. Phys. Chem. A 2010, 114, 2324-2330; (k) Adamczyk-Woźniak, A.; Madura, I.; Velders, A. H.; Sporzyński, A. Tetrahedron Lett. 2010, 51, 61816185; (l) Adamczyk-Woźniak, A.; Fratila, R. M.; Madura, I. D.; Pawełko, A.; Sporzyński, A.; Tumanowicz, M.; Velders, A. H.; Żyła, J. Tetrahedron Lett. 2011, 52, 6639-6642; (m) Adamczyk-Woźniak, A.; Madura, I.; Pawełko, A.; Sporzyński, A.; Żubrowska, A.; Żyła, J. Cent. Eur. J. Chem. 2011, 9, 199-205; (n) Adamczyk-Woźniak, A.; Cyrański, M. K.; Frączak, B. T.; Lewandowska, A.; Madura, I. D.; Sporzyński, A. Tetrahedron 2012, 68, 3761-3767; (o) AdamczykWoźniak, A.; Borys, K. M.; Sporzyński, A. Chem. Rev. 2015, 115, 5224-5247.

6. Akama, T.; Virtucio, C.; Dong, C.; Kimura, R.; Zhang, Y. K.; Nieman, J. A.; Sharma, R.; Lu, X.; Sales, M.; Singh, R.; Wu, A.; Fan, X. Q.; Liu, L.; Plattner, J. J.; Jarnagin, K.; Freund, Y. R. Bioorg. Med. Chem. Lett. 2013, 23, 1680-1683.

7. Bose, A. K.; Srinivasan, P. R. Tetrahedron 1975, 31, 3025-3029. 8. (a) Cammidge, A. N.; Goddard, V. H. M.; Schubert, C. P. J.; Gopee, H.; Hughes, D. L.; Gonzalez-Lucas, D. Org. Lett. 2011, 13, 6034-6037; (b) Fu, Y.; He, Q.; Zhu, D.; Wang, Y.; Gao, Y.; Cao, H.; Cheng, J. Chem. Commun. 2013, 49, 11266-11268.

9. Hargrove, A. E.; Ellington, A. D.; Anslyn, E. V.; Sessler, J. L. Bioconjugate Chem. 2011, 22, 388-396.

10. (a) Zhu, C.; Wang, R.; Falck, J. R. Org. Lett. 2012, 14, 34933497; (b) Lozada, J.; Liu, Z.; Perrin, D. M. J. Org. Chem. 2014, 79, 5365-5368.

11. Wang, L.; Dai, C.; Burroughs, S. K.; Wang, S. L.; Wang, B. Chemistry 2013, 19, 7587-7594.

\section{Supplementary Material}

Supplementary material (details of peptide syntheses and characterization techniques, additional NMR, HPLC, and MS data) associated with this article can be found, in the online version, at. 


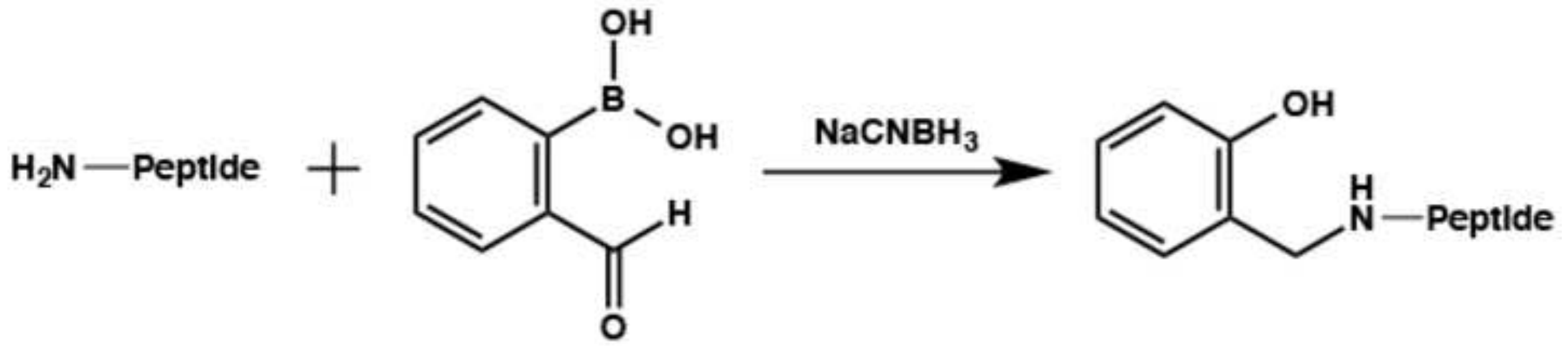

